\title{
Oxygen affinity of blood in altitude Sherpas
}

\author{
MICHELE SAMAJA, ARSENIO VEICSTEINAS, AND PAOLO CERRETELLI \\ Departments of Physiology (III) and Enzymology, University of Milan and Centro Studi di \\ Fisiologia del Lavoro Muscolare del Consiglio Nazionale delle Ricerche, Milan, Italy
}

\begin{abstract}
Samaja, Michele, Arsenio Veicsteinas, and Paolo CerRETELLI. Oxygen affinity of blood in altitude Sherpas. J. Appl. Physiol.: Respirat. Environ. Exercise Physiol. 47(2): 337-341, 1979.-Oxygen equilibrium curves on blood within $6 \mathrm{~h}$ from sampling have been estimated from polarographic measurements of oxyhemoglobin concentration, in 13 male 14- to 50-yr old Sherpas residing at $3,850 \mathrm{~m}$ above sea level (Kumjung, Nepal). In samples with red blood cell counts $=4.7 \pm 0.8$ (SD) $\times 10^{6} / \mathrm{mm}^{3}$, total hemoglobin concentration $[\mathrm{Hb}]=17.0 \pm 1.9$ $\mathrm{g} / \mathrm{dl}$, and hematocrit $=53.3 \pm 5.0$, the mean oxygen halfsaturation of hemoglobin $\left(\mathrm{P}_{50}\right)\left(\mathrm{pH}=7.4\right.$ and $\mathrm{PCO}_{2}=40$ Torr $)$ was $27.3 \pm 1.8$ Torr. The $\mathrm{P}_{50}$ of altitude Sherpas was not significantly different from that of acclimatized lowlanders (28.2 $\pm 1.3 ; n=7)$, sea-level Caucasian residents $(26.5 \pm 1.0 ; n=17)$, and Sherpas at sea level (27.1; $n=3)$. 'The 2,3-diphosphoglyceric acid-to-hemoglobin concentration ratio $([2,3-\mathrm{DPG}] /[\mathrm{Hb}])$ in altitude Sherpas was $1.22 \pm 0.03$, the same as that of acclimatized Caucasians $(1.22 \pm 0.10)$. The Bohr effect measured for the blood of one altitude Sherpa by the ratio $\Delta \log \mathrm{P}_{50} / \Delta \mathrm{pH}$ was -0.32 and -0.45 at $\mathrm{PCO}_{2}$ levels of 40 and 20 Torr, respectively. These values are not significantly different from those found in Caucasians at sea level where $\Delta \log \mathrm{P}_{50} / \Delta \mathrm{pH}$ was -0.35 and -0.42 , respectively. It is concluded that the $\mathrm{P}_{50}$ in native highlanders is not significantly different from that observed in sealevel dwellers. [2,3-DPG]/[Hb] at altitude, both in natives and in newcomers, is $20 \%$ higher than in sea-level residents.
\end{abstract}

oxygen half-saturation pressure of hemoglobin; 2,3-diphosphoglyceric acid; Sherpas; oxyhemoglobin dissociation curve; altitude natives; oxygen transport at altitude

SHERPAS HAVE BEEN LIVING in the Himalayas of Tibet and Nepal for centuries. With the exception, perhaps, of some Andean communities living at altitude, the Sherpa is the only group adapted to hypoxia and well known for its outstanding performance in mountaineering and for carrying heavy loads at extreme altitude. Moreover, the physical working capacity and the endurance of the Sherpas have been found to exceed that of other Tibetan, Indo-Nepali, and Indian populations living for several generations in the same or in nearby regions as well as that of acclimatized Caucasians (10).

The consensus is, even though experimental evidence is lacking, that the Sherpa's average maximal aerobic power $\left(\mathrm{Vo}_{2}\right.$ max $)$ at a given altitude is higher than for Caucasians or other neighboring groups and/or that the relative drop of $\dot{\mathrm{V}}_{2}$ max caused by hypoxia is less. Several factors, both of physiological and biochemical nature, have been proposed to explain this behavior. Among these factors is an improved blood oxygen transport due to interactions between hemoglobin $(\mathrm{Hb})$ and other mol- ecules such as $\mathrm{CO}_{2}$ and 2,3-diphosphoglyceric acid (2,3DPG). However, a review of the literature on the subject of hemoglobin-oxygen $\left(\mathrm{Hb}-\mathrm{O}_{2}\right)$ affinity of high-altitude natives from the Andes and the Himalayas leads to rather controversial results, as shown in Table 1. Apart from possible genetic differences among the investigated populations, these conflicting findings, particularly those concerning the value of oxygen half-saturation of hemoglobin $\left(\mathrm{P}_{50}\right)$, may be the consequence of ignoring or overlooking some variables known to affect the $\mathrm{Hb}-\mathrm{O}_{2}$ interactions. In addition, the way blood samples were collected, stored, transferred to the laboratory, and analyzed by different investigators may be the cause of some of the strikingly discordant results that from time to time have been published. Therefore, to gain some insight into the functional characteristics of the hemoglobin properties of high-altitude natives, a field laboratory was set up at Kumjung $(3,850 \mathrm{~m}$ above sea level), a Sherpa settlement of the Khumbu Valley in Northeast Nepal. In addition, arrangements were made to collect blood from a group of Caucasians temporarily residing in the Western Alpine Range at an altitude of $3,500 \mathrm{~m}$ above sea level and from 17 healthy subjects at sea level (Milan, $122 \mathrm{~m}$ above sea level).

In all cases, all analyses except electrofocusing of hemoglobin were performed within $6 \mathrm{~h}$ from blood sampling, no matter whether blood was drawn in the field or in the laboratory.

\section{MATERIALS AND METHODS}

The experiments were conducted on a total of 40 male subjects: 13 Sherpas (14-50 yr old) permanently living and working at altitudes between 3,000 and $4,500 \mathrm{~m}$ above sea level (group $S h_{\text {nat }}$ ); 7 Italians $(22-29$ yr old) working in an alpine resort, after a 3- to 5-day continuous sojourn at or following 2-8 mo of 8-h daily exposure to an altitude of $3,500 \mathrm{~m}$ (group $\left.I t_{a c c l}\right) ; 17$ nonacclimatized Italians (21-35 yr old) (group It $\left.t_{s l}\right)$; and 3 Sherpas (18-21 yr old) natives of Kumjung $(3,850 \mathrm{~m})$ after a sojourn of about $3 \mathrm{yr}$ at $1,450 \mathrm{~m}$ above sea level followed by a further 3-mo stay at sea level (group $S h_{s l}$ ).

Blood samples were taken from the antecubital vein, heparinized, and stored at $0^{\circ} \mathrm{C}$. All analyses were performed in duplicate and occasionally in triplicate.

Hemoglobin concentration, hematocrit (Hct), and red blood cell counts (RBC) were determined by standard laboratory procedures. [2,3-DPG] was determined by the end-point method of Rose and Liebowitz (18). $P_{50}$ was estimated by a modified version of the method described 
TABLE 1. $P_{50}$ and $[2,3-D P G] /[H b]$ at sea level and in acute and chronic hypoxic and altitude natives

\begin{tabular}{|c|c|c|c|c|c|c|c|c|c|}
\hline \multicolumn{2}{|c|}{ Sea Level } & \multirow{2}{*}{$\begin{array}{l}\text { Altitude, } \\
\mathrm{m}\end{array}$} & \multicolumn{2}{|c|}{ Acute Hypoxia ( $<4$ days) } & \multicolumn{2}{|c|}{ Chronic Hypoxia ( $>4$ days) } & \multicolumn{2}{|c|}{ Natives } & \multirow[b]{2}{*}{ Refs. } \\
\hline P.⿲丿丨 Torr & $\begin{array}{c}{[2,3 \cdot \mathrm{DPG}] /[\mathrm{Hb}]} \\
\mathrm{mol} / \mathrm{mol}\end{array}$ & & $P_{* x,}$ Torr & $\begin{array}{c}{[2,3-\mathrm{DPG}] /[\mathrm{Hb}]} \\
\mathrm{mol} / \mathrm{mol}\end{array}$ & $P_{\text {sul }}$, Torr & $\begin{array}{c}{[2,3-\mathrm{DPG}] /[\mathrm{Hb}]} \\
\mathrm{mol} / \mathrm{mol}\end{array}$ & $P_{*}$ & $\begin{array}{c}{[2,3-\mathrm{DPG}] /[\mathrm{Hb}]} \\
\mathrm{mol} / \mathrm{mol}\end{array}$ & \\
\hline $24.4 \pm 0.8$ & & 4,540 & $25.2 \pm 0.8$ & & $26.1 \pm 1.7$ & & $26.1 \pm 1.7(\mathrm{I})$ & & $\begin{array}{l}\text { Aste-Salazar \& } \\
\text { Hurtado (2) }\end{array}$ \\
\hline 26.0 & & 4,000 & 27.6 & & 26.6 & & 26.6 (I) & & Chiodi (5) \\
\hline 26.7 & & 3,500 & 31.2 & & 29.9 & & & & $\begin{array}{l}\text { Mulhausen et al. } \\
\text { (16) }\end{array}$ \\
\hline $26.6 \pm 0.3$ & 0.61 & 4,500 & $31.0 \pm 0.4$ & 0.94 & $27.3 \pm 0.8$ & 0.57 & $30.7 \pm 0.6(\mathrm{I})$ & 0.80 & Lenfant et al. (12) \\
\hline $28.3 \pm 0.6(\mathrm{I})$ & 0.49 & & & & & & & & \\
\hline & 0.75 & 3,700 & & & & 0.84 & & & Eaton \& Brewer (8) \\
\hline $26.8 \pm 0.6$ & & 4,500 & & & $30.4 \pm 0.9$ & & $30.6 \pm 0.7$ (I) & & Lenfant et al. (13) \\
\hline $26.7 \pm 0.1$ & 0.94 & 4,300 & & & & & $29.8(\mathrm{I})$ & & Torrance et al. (22) \\
\hline $26.6 \pm 0.3$ & 0.91 & 4,500 & 30.6 & 1.15 & & & & & Lenfant et al. (14) \\
\hline $26.2 \pm 1.0$ & & 4,500 & $26.3 \pm 1.2$ & & $27.5 \pm 1.4$ & & & & $\begin{array}{l}\text { Weiskopf \& } \\
\text { Severinghaus } \\
\text { (23) }\end{array}$ \\
\hline 26.3 & 0.74 & 3,800 & 28.0 & 0.99 & & & & & $\begin{array}{l}\text { Cymerman et al. } \\
\text { (6) }\end{array}$ \\
\hline $\begin{array}{l}\text { Means } \\
26.3\end{array}$ & 0.76 & & 28.5 & 1.03 & 28.2 & 0.90 & $28.8(\mathrm{I})$ & 0.80 & \\
\hline $27.0 \pm 1.0$ & 0.88 & 3,900 & & & 30.0 & 1.26 & $22.6 \pm 0.5(\mathrm{~S})$ & 0.90 & $\begin{array}{l}\text { Morpurgo et al. } \\
\text { (15) }\end{array}$ \\
\hline $36.7(\mathrm{~S})$ & 1.36 & & & & & & & & \\
\hline
\end{tabular}

Values are means \pm SD. I, American Indians; S, Sherpas (Himalaya).

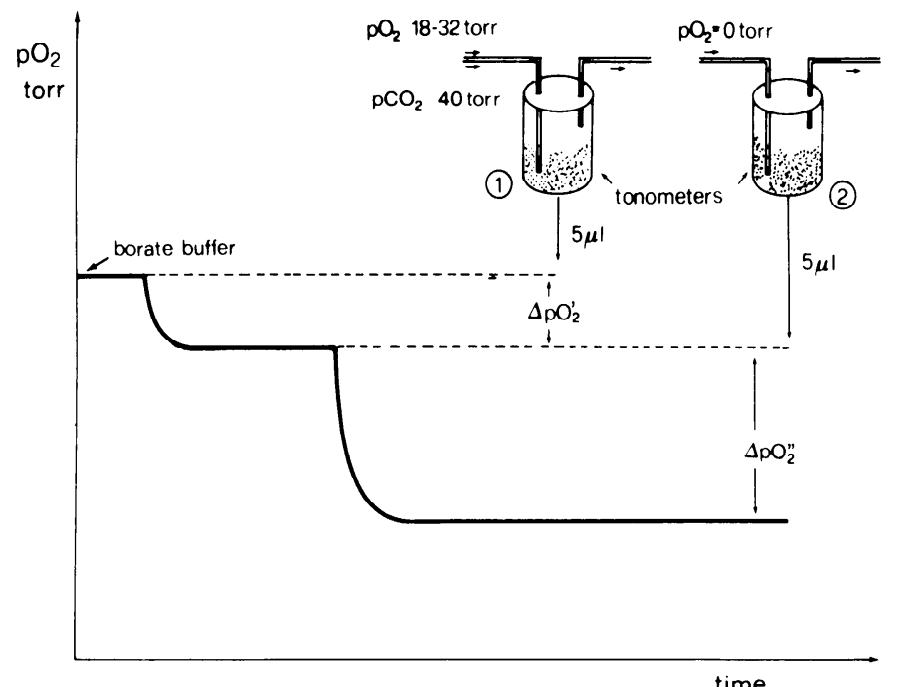

FIf. 1. Scheme of method used for estimation of oxygen saturation of blood at fixed Po... Explanations in text.

by Rossi-Bernardi et al. (20). The following procedure, particularly suited for field measurements, was adopted. Two small amounts ( $50 \mu \mathrm{l}$ each) of the same well-stirred blood sample were equilibrated for $6 \mathrm{~min}$ in an AMT 1 Åstrup microtonometer (Radiometer, Copenhagen) at $37^{\circ} \mathrm{C}$, one with a ternary gas mixture provided by a mixing pump (H. Wösthoff type $1 \mathrm{M} 301 / \mathrm{a}-\mathrm{F}$, Bochum) $\left(\mathrm{PO}_{2}\right.$ range $=18-32$ torr, $\mathrm{PCO}_{2}=40$ torr, $\mathrm{PN}_{2}$ to barometric pressure), the other with pure nitrogen (Fig. 1, top).

Hemoglobin-oxygen saturation was determined as

$$
\% \mathrm{HbO}_{2}=\frac{[\text { total } \mathrm{Hb}]-[\text { deoxy } \mathrm{Hb}]}{[\text { total } \mathrm{Hb}]} \times 100
$$

where [total $\mathrm{Hb}$ ] was the "active" $\mathrm{Hb}$, i.e., all hemoglobin after subtraction of carboxyhemoglobin ( $\mathrm{HbCO}$ ) and methemoglobin (metHb) and [deoxy $\mathrm{Hb}]$ was the deoxygenated $\mathrm{Hb}$.

The latter fraction was estimated by adding by a micropipette (SMI, Micropettor) $5 \mu \mathrm{l}$ of the partially deoxygenated sample from tonometer 1 to $1 \mathrm{ml}\left(37^{\circ} \mathrm{C}\right)$ of a $10-\mathrm{mM}$ tetraborate buffer $(\mathrm{pH} \simeq 9)$. The buffer, containing an hemolyzing agent $(0.1 \%$ Sterox SE) was previously equilibrated with air in the anaerobic cuvette described by Rossi-Bernardi et al. (19). Adding a small amount of a partially deoxygenated blood sample to the tetraborate buffer resulted in a drop of the oxygen partial pressure $\left(\mathrm{Po}_{2}\right)$ of the solution which was monitored by an $\mathrm{O}_{2}$ microelectrode. This drop $\left(\Delta \mathrm{Po}_{2}{ }^{\prime}\right)$ was proportional to [deoxy $\mathrm{Hb}$ ] and was due to the sudden oxygenation of deoxy $\mathrm{Hb}$ molecules following the shift to the left of the $\mathrm{HbO}_{2}$ dissociation curve, prompted by the peculiar conditions of the sample, i.e., hemolysis, low [Hb], and alkaline $\mathrm{pH}$.

The addition of $5 \mu \mathrm{l}$ of the $\mathrm{N}_{2}$-equilibrated blood sample from tonometer 2 to the same blood buffer solution caused a further drop of $\mathrm{Po}_{2}\left(\Delta \mathrm{Po}_{2}{ }^{\prime \prime}\right) . \Delta \mathrm{Po}_{2}{ }^{\prime \prime}$ was proportional to the total $[\mathrm{Hb}]$, inasmuch as the added blood was fully deoxygenated. The volumes and the [Hb] of the two blood samples added were the same, and consequently any present $\mathrm{HbCO}$ and/or metHb would be the same in the two samples. Thus, $E q .1$ can be

$$
\% \mathrm{HbO}_{2}=\frac{\Delta \mathrm{Po}_{2}{ }^{\prime \prime}-\Delta \mathrm{Po}_{2}{ }^{\prime}}{\Delta \mathrm{Po}_{2}{ }^{\prime \prime}} \times 100
$$

from which the $\mathrm{O}_{2}$ saturation at given $\mathrm{PO}_{2}$ (e.g., in the range 18-32 Torr, as in Fig. 1) can be obtained. pH was determined by a microelectrode (BMS 3, Mk2, Radiometer) just after the second addition of blood. The $\mathrm{pH}$ ranges after tonometry (mean $\mathrm{PCO}_{2} \simeq 40$ Torr) was 7.30 to 7.41 for group $S h_{\text {ral }}, 7.34$ to 7.37 for $I t_{a c c l}$, and 7.37 to 7.42 for $I t_{s l}$. 
For $\% \mathrm{HbO}_{2}$ values from 30 to 70 approximately, $\mathrm{P}_{50}$ was obtained by extrapolation from Hill's plot assuming an $n$ coefficient of 2.6 . Values of 2.6 for $n$ were recently obtained by Winslow et al. (24) and also found for some of the subjects (both lowlanders and highlanders) appearing in the present study as a result of preliminary $\% \mathrm{HbO}_{2}$ determinations at two $\mathrm{Po}_{2}$ levels, one below and the other above the expected $\mathrm{P}_{50}$. It must be pointed out that the $P_{50}$ value obtained by the above procedure is not influenced by possible changes of [2,3-DPG] levels. In fact, it was observed (21) that an increase of blood 2,3DPG up to $200 \%$ of its normal level affected the value of $n$ less than $5 \%$. Moreover, the experimental oxygen saturation in most cases (at least one of two or three analyses) was close to $50 \%$ minimizing the possible errors in the extrapolation.

To determine the Bohr effect, appropriate $\mathrm{N}_{2}-\mathrm{O}_{2}-\mathrm{CO}_{2}$ mixtures were selected while the $\mathrm{pH}$ of the samples was changed by adding variable amounts of isotonic (0.1 M $\mathrm{NaOH}$ or $0.02 \mathrm{M} \mathrm{HCl}$ to the blood prior to tonometry. The Bohr effect was then calculated as the slope of a log $\mathrm{P}_{50}$ vs. $\mathrm{pH}$ regression at constant $\mathrm{PCO}_{2}$.

Electrofocusing of hemoglobin of some of the blood samples stored in ice for about 5 days were performed in the laboratory.

\section{RESULTS}

Table 2 summarizes all measurements. Compared to sea-level controls, $\mathrm{RBC}$, [Hb], and Hct are higher in both high-altitude Sherpa natives and acclimatized Italians with no appreciable differences between the two groups. Moreover, high-altitude natives brought to sea level show a blood pattern similar to that of sea-level dwellers.

No significant differences in $\mathrm{P}_{50}$ were found among the various groups. It must be emphasized that all the $\mathrm{P}_{50}$ values of Table 2 refer to standard conditions of $\mathrm{PCO}_{2}(40$ Torr), $\mathrm{pH}(7.4)$, and temperature $\left(37^{\circ} \mathrm{C}\right)$. These are not physiological values but indicate the "in vitro" oxygen carrying properties of blood that appears nearly unchanged under the various investigated conditions. While in high-altitude subjects $\left(S h_{\text {nat }}\right.$ and $\left.I t_{a c c l}\right)$ the $\mathrm{P}_{50}$ was not significantly changed compared to sea level $(0.1<P<$ $0.2)$ the $[2,3-\mathrm{DPG}]$ was significantly $(P<0.001)$ higher.

In a single native Sherpa whose $P_{50}$ was close to the mean value for the group, the Bohr effect was measured in triplicate at constant $\mathrm{PCO}_{2}$ values of 40 and 20 Torr, respectively. The $\log \mathrm{P}_{50} / \mathrm{pH}$ lines (not shown) appear to be shifted upward compared to sea-level controls. The

TABle 2. Hematologic values and $P_{50}$ at standard conditions of four groups of subjects

\begin{tabular}{|c|c|c|c|c|}
\hline & \multicolumn{2}{|c|}{ Sea Level } & \multicolumn{2}{|c|}{ Altitude } \\
\hline & $\begin{array}{c}I t_{* \prime} \\
=17)\end{array}$ & $\begin{array}{c}S h_{1} \\
(n=3)\end{array}$ & $\begin{array}{c}I t_{t a v e l} \\
(n \stackrel{7}{=} 7)\end{array}$ & $\begin{array}{c}S h_{n+1} \\
(n=13)\end{array}$ \\
\hline$[\mathrm{Hb}], \mathrm{g} / \mathrm{dl}$ & $15.5 \pm 1.0$ & 14.5 & $17.6 \pm 1.2$ & $17.0 \pm 1.9$ \\
\hline Hct, \% & $47.7 \pm 3.0$ & 46.0 & $50.0 \pm 1.4$ & $53.3 \pm 5.0$ \\
\hline $\mathrm{RBC} \times 10^{6} / \mathrm{mm}^{3}$ & $4.71 \pm 0.2$ & 4.9 & $5.4 \pm 0.3$ & $4.7 \pm 0.8$ \\
\hline $\begin{array}{l}\mathrm{P}_{50}, \text { Torr }(\mathrm{pH}=7.4 \\
\left.\mathrm{PCO}_{2}=40 \text { Torr }\right)\end{array}$ & $26.5 \pm 1.0$ & 27.1 & $28.2 \pm 1.3$ & $27.3 \pm 1.8$ \\
\hline [2,3-DPG]/[Hb], & $0.97 \pm 0.09$ & 1.1 & $1.22 \pm 0.1$ & $1.22 \pm 0.03$ \\
\hline
\end{tabular}

$\mathrm{mol} / \mathrm{mol}$

\footnotetext{
Values are means \pm SD. For explanations, see text.
}

slope $\left(\Delta \log \mathrm{P}_{50} / \Delta \mathrm{pH}\right)$ at $\mathrm{PCO}_{2}=40$ Torr was found to be -0.35 , i.e., not substantially different from that of a sealevel control $(-() .32)$. The above values are similar to the standard value of -0.37 found by Wranne et al. (25) on normal individuals at sea level. At $\mathrm{PCO}_{2}=20$ Torr, the $\Delta \log \mathrm{P}_{50} / \Delta \mathrm{pH}$ was -0.45 in the Sherpa and -0.42 in the lowlander.

The electrophoretic pattern of the Hb of the Sherpas indicates the presence of $\mathrm{HbA}$ and $\mathrm{HbA}_{2}$ in the proportion normally found in Caucasians.

\section{DISCUSSION}

The blood pattern of native Sherpas at a given altitude does not differ significantly from that of acclimatized Caucasians except for their relatively low $\mathrm{RBC}$ for similar hematocrit. This observation confirms previous findings by Cerretelli (3) and Morpurgo et al. (15) on a different group of Khumbu Valley natives.

The results appearing in Table 2 indicate that 1) the mean standard $\mathrm{P}_{50}$ of the Sherpas was the same as that of the controls; 2 ) the average $[2,3-\mathrm{DPG}] /[\mathrm{Hb}]$ was markedly higher in Sherpas than in sea-level controls, although not different from that of acclimatized Caucasians; and 3) all blood variables of Sherpas at sea level were within the normal range for sea-level dwellers.

Oxygen affinity of Sherpa blood. Sherpas do not show the decrease of blood $\mathrm{O}_{2}$ affinity described in Andean natives by Lenfant et al. $(12,13)$ as well as by Torrance et al. (22). The present data are in contrast with the results of the only other known investigation on Sherpas by Morpurgo et al. (15). These authors found in a group of seven individuals a remarkably higher blood $\mathrm{O}_{2}$ affinity $\left(\mathrm{P}_{50}=22.6\right.$ Torr, see Table 1$)$. Time from sampling seems to play a key role in these measurements. In fact, as recently shown by Aberman et al. (1) and Hellerstein and Bunthrarungroj (9), the $\mathrm{P}_{50}$ of a blood sample decreases markedly after a few hours of storage even in an ice bath. The observed discrepancy between the $P_{50}$ values obtained in the present study and those observed by Morpurgo et al. (15) could be dependent on the different time between sampling and analysis elapsed in the two cases. This was less than $6 \mathrm{~h}$ for the present measurements as opposed to 5 days in the investigation by Morpurgo et al. (15).

2,3-DPG concentration, altitude hypocapnia, and the Bohr effect. The larger concentrations of 2,3-DPG, when expressed in a mole-to-mole ratio to $\mathrm{Hb}$, found in the blood of both native Sherpas and acclimatized Caucasians, confirm previous observations made on Andean natives (22). Increased [2,3-DPG] prompted by the increase of [deoxy $\mathrm{Hb}$ ] at altitude (7) decreases the $\mathrm{O}_{2}$ affinity of oxyhemoglobin. This is an adaptive mechanism favoring $\mathrm{O}_{2}$ release despite low blood $\mathrm{O}_{2}$ content. It should be pointed out, however, that at altitude the physiological levels of $\mathrm{P}_{50}$ are mainly the result of at least two counterbalancing effects: $a$ ) the increase of [2,3DPG] and $b$ ) the decrease of arterial $\mathrm{PCO}_{2}$ due to hypoxic hyperventilation leading to an increased $\mathrm{O}_{2}$ affinity and therefore to a lower $\mathrm{P}_{50}$. If the Bohr effect at the same $\mathrm{PCO}_{2}$ is the same in Sherpas and in lowlanders as it appears from the determination carried out in one of the subjects of the present study, the interaction of the above 
mechanisms may lead to physiological $\mathrm{P}_{50}$. In fact, in a Sherpa whose standard $P_{50}$ value was found to be 28 Torr, the $\mathrm{P}_{50}$ was 26 Torr, when measured "in vivo" at $\mathrm{pH}=7.4$ and $\mathrm{PCO}_{2}=25$ Torr. This in vivo value is within the normal range for nonacclimatized subjects.

Considering that the electrophoretic pattern of $\mathrm{Hb}$ also did not reveal the presence of abnormal hemoglobins, the above results rule out the hypothesis that the Sherpas could be characterized by a genetic or acquired facilitated $\mathrm{O}_{2}$ transport mechanisms.

$\mathrm{O}_{2}$ transport mechanisms, maximal aerobic power, and performance of the Sherpa. The outstanding performances of altitude Sherpas cannot be explained with an improved blood $\mathrm{O}_{2}$ affinity. On the other hand, there is some recent experimental evidence (4) indicating that the Sherpas are not characterized, as it had been claimed, by a higher average specific (per unit body weight) $\dot{\mathrm{Vo}}_{2 \text { max }}$ than any acclimatized or even nonacclimatized Caucasian group.

Measurements of $\mathrm{V}_{2 \max }$ carried out at $5,350 \mathrm{~m}$ above sea level by one of us (4) on a group of 21 male natives of the Khumbu Valley of Nepal (3,200-3,900 m above sea level) yielded a mean value of $39.7 \pm 7.1$ (SD) $\mathrm{ml} \cdot \mathrm{kg}^{-1}$. $\min ^{-1}$, a value not significantly different from $36.8 \pm 4.5$ found at the same altitude in a group of 32 well-acclimatized Italian amateur mountaineers. The $\dot{\mathrm{V}}_{2}$ max of a group of 16 Sherpa natives of Kumjung $(3,850 \mathrm{~m})$, including most of the subjects whose blood pattern appears in Table $2\left(S h_{\text {nat }}\right)$, was found to be $40.6 \pm 7.7 \mathrm{ml} \cdot \mathrm{kg}^{-1}$. $\mathrm{min}^{-1}$, not greatly different from the value of $37.4 \pm 2.1$ $\mathrm{ml} \cdot \mathrm{kg}^{-1} \cdot \mathrm{min}^{-1}$ of 5 Italians and from the average value

\section{REFERENCES}

1. Aberman, A., J. M. Cavanilles, S. Michaels, S. H. Shubin, and M. H. WEIL. In vitro changes in blood $P_{50}$ and erythrocyte 2,3diphosphoglycerate concentration. Clin. Chem. 22: 1073-1077, 1976

2. Aste-Salazak, H., and A. Hurtado. The affinity of hemoglobin for oxygen at sea level and at high altitudes. Am. J. Physiol. 142 $733-743,1944$.

3. Cerretelli, P. Limiting factors to oxygen transport on Mount Fverest. J. Appl. Physiol. 40: 658-667, 1976.

4. Cerretelli, P. Metabolismo ossidativo ed anaerobico nel soggetto acclimatato all'altitudine. Minerva Med. 67: 11-26, 1976.

5. Chioni, H. Respiratory adaptations to chronic high altitude hypoxia. J. Appl. Physiol. 10: 81-87, 1957.

6. Cymprman, A., J. T. Maher, J. C. Cruz, J. T. Refeves, J. C. Denniston, and R. F. Grover. Increased 2,3-diphosphoglycerate during normocapnic hypobaric hypoxia. Aviat. Space Environ. Med. 47: 1069-1072, 1976.

7. Duhm, J., and E. Gerlach. On the mechanism of the hypoxia induced increase of 2,3-diphosphoglycerate. Pfluegers Arch. 326: $254-269,1971$

8. Eaton, I. W., AND J. Brfwer. The relationship between red cell, 2,3-diphosphoglycerate and levels of hemoglobin in the human Proc. Natl. Acad. Sci. USA 61: 756-760, 1968.

9. Hellerstein, S., and 'T. BunthrarungroJ. Effect of time and temperature on blood $\mathrm{P}_{5, \mathrm{~s}}$ and 2,3-diphosphoglycerate measurements. Clin. Chem. 22: 39-41, 1976.

10. Kenntner, G. Gebraüche and Leistungsfähigkeit im Tragen von Lasten bei Bewonern des südlichen Himalaya. Z. Morphol. Anthropol. 61: 125-169, 1969.

11. Lahiri, S., J. S. Milifedge, H. P. Chattopadhyay, A. K. BhatTACHAKY YA, AND A. K. Sinha. Respiration and heart rate of Sherpa highlanders during exercise. J. Appl. Physiol. 23: 545-554, 1967.

12. Lenfant, C., J. Torrance, E. English, C. A. Finch, C. ReynaFARJE, J. RAmos, aND J. FAURA. Effect of altitude on oxygen of $39.4 \pm 3.9 \mathrm{ml} \cdot \mathrm{kg}^{-1} \cdot \mathrm{min}^{-1}$ observed in a group of untrained unacclimatized Italians $(n=26)$ in a decompression chamber (4) at 3,750 $\mathrm{m}$ above sea level.

Also the mechanical efficiency of a familiar exercise such as stepping up and down from a $30-\mathrm{cm}$ bench was found to be the same in 21 Sherpas and 15 Italians at $5,350 \mathrm{~m}$ above sea level (4). This fact rules out the possibility that the better performance of the Sherpas may depend on a more efficient mechanochemical coupling at the muscle level. There is the possibility, however, that in the Sherpas the muscle involved in locomotion may have a better $\mathrm{O}_{2}$ supply at the expense of other muscles, e.g., those activating the ventilatory pump.

It is well known (11) that high-altitude natives ventilate less for a given work load. Even though the energy involved in the work of breathing appears to be in ordinary conditions only a small fraction of the overall energy consumption (17), it may become critical at the very high ventilation rates attained at extreme altitudes, thus improving the physical working capacity of the Sherpas compared to newcomers.

In conclusion, it appears that native Sherpas cannot be characterized by any special feature in terms of either blood $\mathrm{O}_{2}$ affinity and/or overall $\dot{\mathrm{V}}_{2}$ max. This does not rule out the possibility that other factors of physiological (e.g., work of breathing) or perhaps psychological nature may actually improve their maximal performance, particularly at extreme altitude.

Received 30 January 1979; accepted in final form 10 April 1979.

binding by hemoglobin and on organic phosphate levels. J. Clin. Invest. 47: 2652-2656, 1968.

13. Lenfant, C., P. Ways, C. Aucutt, and J. Cruz. Effect of chronic hypoxic hypoxia on the $\mathrm{O}_{2}-\mathrm{Hb}$ dissociation curve and respiratory gas transport in man. Respir. Physiol. 7: 7-29, 1969

14. Lenfant, C., J. D. Torrance, and J. Reynafarje. Shift of the $\mathrm{O}-\mathrm{Hb}$ dissociation curve at altitude: mechanism and effect. J. Appl. Physiol. 305: 625-631, 1971.

15. Morpurgo, G., P. Arese, A. Bosia, G. P. Pescarmona, M. LuzZana, G. Modiano, and S. Krishna Ranjit. Sherpas living permanently at high altitude: a new pattern of adaptation. Proc. Natl. Acad. Sci. USA 73: 747-751, 1976.

16. Mulhausen, R. O., B. Åstrup, and K. Mellemgaard. Oxygen affinity and acid-base status of human blood during exposure to hypoxia and carbon monoxide. Scand. J. Clin. Lab. Invest. Suppl. 103: 9-15, 1968.

17. OTIs, A. B. The work of breathing. In: Handbook of Physiology. Respiration. Washington, DC: Am. Physiol. Soc., 1964, sect. 3, vol. I, chapt. 17 , p. $463-476$.

18. Rose, Z. B., and J. Liebowitz. Direct determination of 2,3-diphosphoglycerate. Anal. Biochem. 35: 177-180, 1970.

19. Rossi-Bernardi, L., M. Luzzana, M. Samaja, M. Davi, B. SkaTon, D. Da Riva-Ricci, J. Minoli, and R. L. Berger. Continuous determination of the oxygen dissociation curve for whole blood. Clin. Chem. 21: 1747-1753, 1975.

20. Rossi-Bernardi, L., M. Perrella, M. Luzzana, M. Sama.ja, and I. RAFFAELE. Simultaneous determination of hemoglobin derivates, oxygen content, oxygen capacity and oxygen saturation in $10 \mu \mathrm{l}$ of whole blood. Clin. Chem. 23: 1215-1225, 1977.

21. Samaja, M., and R. M. Winslow. The separate effects of $\mathrm{H}^{+}$and 2,3-DPG on the oxygen equilibrium curve of human blood. $\mathrm{Br} . \mathrm{J}$. Haematol. 41: 373-382, 1979.

22. Torrance, J. D., C. Lfenfant, J. Cruz, and F. Marticorena. 
Oxygen transport mechanisms in residents at high altitude. Respir. Physiol. 11: 1-15, 1970/71.

23. Weiskopf, R. B., AND J. W. Severinghaus. Lack of effect of high altitude on hemoglobin oxygen affinity. J. Appl. Physiol. 33: 276$277,1972$.

24. Winslow, R. M., M. L. S. Wenberg, R. L. Berger, R. J. Shrager,
M. Luzzana, M. Samaja, and L. Rossi-Bernardi. Oxygen equilibrium curve of normal human blood and its evaluation by Adair's equation. J. Biol. Chem. 252: 2331-2337, 1977.

25. Wranne, B., R. D. Woodson, and J. C. Detter. Bohr effect: interaction between $\mathrm{H}^{+}, \mathrm{CO}_{2}$, and 2,3-DPG in fresh and stored blood. J. Appl. Physiol. 32: 749-754, 1972.

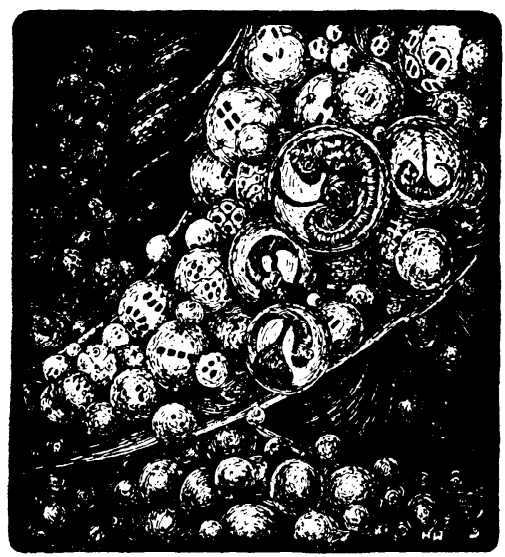

